UDC 547.495.2+547.785.2

\author{
V.R. Kushcherbaeva ${ }^{1}$, A.A. Bakibaev ${ }^{1}$, D.A. Kurgachev' ${ }^{2}$, \\ A.G. Zhaksybaeva ${ }^{3}$, V.S. Malkov ${ }^{1}$, O.A. Kotelnikov ${ }^{1}$ \\ ${ }^{I}$ Tomsk State University, Russia; \\ ${ }^{2}$ Tomsk Polytechnic University, Russia; \\ ${ }^{3}$ L.N. Gumilyov Eurasian National University, Astana, Kazakhstan \\ (E-mail: kuscherbaeva_venera@mail.ru)
}

\title{
Study of acid catalyzed synthesis and analytical preparative separation of the spatial isomers of $\mathrm{N}, \mathrm{N}$-dimethylglycoluril
}

\begin{abstract}
Alkylglycolurils are promising class of organic compounds characterized by a wide spectrum of psychopharmacological activity such as tranquilizing, neuroleptic, antidepressant and psychostimulating. However, there are conflicting data on the methods of obtaining and identifying isomers of N,N'-dimethylglycoluril in the literature. Our aim is to study the reaction of glyoxal with $\mathrm{N}$-methylurea in acid-catalyzed conditions in various media, develop analytical, preparative separation and identify regioisomers. We developed a method for separating the trans- and cis- isomers of N,N'-dimethylglycoluril by high-performance liquid chromatography. As a result of this analysis, it was possible to separate the cis- and trans- isomers of N,N'-dimethylglycoluril with retention times, namely, for trans it was $6.998 \mathrm{~min}$ and for cis- was $9.704 \mathrm{~min}$. We proposed an alternative method based on preliminary thin-layer chromatography control of the reaction mass to expand the preparative possibilities for the separation of regioisomers of dimethylglycoluril, and their subsequent separation by column chromatography. Comparison of the samples of compounds $1 \mathrm{a}$ and $1 \mathrm{~b}$ obtained by preparative highperformance liquid chromatography and column chromatography showed complete identity of their physicochemical. It was also established that the reaction of glyoxal with $\mathrm{N}$-methylurea under strong acid conditions was completed mainly by formation of the trans-isomer, in some cases reaching $90 \%$ of regiospecificity. In addition, the combination of physicochemical studies of the cis- and trans- isomers of has made it possible to reliably and unambiguously characterize these isomers.
\end{abstract}

Keywords: glycoluril, dimethylglycoluril, urea, heterocycles, cyclization, high-performance liquid chromatography, column chromatography, preparative chromatography.

\section{Introduction}

$\mathrm{N}$-methylglycolurls are known as neurotropic drugs and used in clinical practice (mebicar, albicar) $[1,2]$. At the same time, their structural precursors $N, N^{\prime}$-dimethylglycolurils (N,N'-DMGU) do not have their own specific neurotropic activity but they can act as one of the probable metabolic products of mebicar. N,N'-DMGU has the cis- and trans- isomer forms and therefore they are of interest to study their physical and chemical properties. A number of studies [3-6] indicate that the bicyclization reaction of glyoxal with $\mathrm{N}$-methylurea in aqueous or alcoholic medium in the presence of hydrochloric acid leads to formation of regioisomers $1 \mathrm{a}, 1 \mathrm{~b}$ with a predominance of trans- isomer $1 \mathrm{a}$ (up to $75 \%$ ). But there is no study of this reaction in acid-catalyzed conditions in various media and information about physico-chemical properties of regioisomers $1 \mathrm{a}, 1 \mathrm{~b}$ isolated by fractional crystallization is far from simple and often contradictory. In the light of the foregoing, our aim is to study the reaction of glyoxal with $\mathrm{N}$-methylurea in acid-catalyzed conditions in various media, develop analytical, preparative separation and identify regioisomers $1 \mathrm{a}, 1 \mathrm{~b}$.

\section{Experimental}

\section{2,4- and 2,6-dimethylglycoluril}

Mixture of isomers $1 \mathrm{a}, 1 \mathrm{~b}$ was synthesized by reaction of glyoxal with methylurea [3]. There were obtained white crystals with $\mathrm{mp} 250^{\circ} \mathrm{C}$. Yield was 26-42\%. 1a: NMR ${ }^{1} \mathrm{H}\left(\mathrm{DMSO}-\mathrm{d}_{6}\right), \delta$ ppm: $7.57(\mathrm{~s}, 2 \mathrm{H})$, $5.10(\mathrm{~s}, 2 \mathrm{H}), 2.60(\mathrm{~s}, 6 \mathrm{H}) . \mathrm{NMR}{ }^{13} \mathrm{C}\left(\mathrm{DMSO}_{6}\right), \delta \mathrm{ppm}: 27.42-\mathrm{CH}_{3}, 67.39(-\mathrm{CH}<), 159.66(>\mathrm{C}=\mathrm{O})$. 1b: NMR ${ }^{1} \mathrm{H}(\mathrm{DMSO}), \delta \mathrm{ppm}: 7.397 \mathrm{~s}(2 \mathrm{H}, \mathrm{NH}), 5.18 \mathrm{~d}(1 \mathrm{H}, \mathrm{CH}), 5.15 \mathrm{~d}(1 \mathrm{H}, \mathrm{CH}), 2.78 \mathrm{~s}\left(6 \mathrm{H}, \mathrm{CH}_{3}\right)$. ${ }^{13} \mathrm{C}$ NMR spectrum (DMSO), $\delta$ ppm: $27.43\left(-\mathrm{CH}_{3}\right), 67.39(-\mathrm{CH}<), 75.63(-\mathrm{CH}<), 160.19(>\mathrm{C}=\mathrm{O})$.

Thin layer chromatography

Sorbfil plates on an aluminum substrate PTSX-AF-A were used to identify the dimethylglycoluril isomers by the thin-layer chromatography method. The particle size of the sorbent was $5-17 \mu \mathrm{m}$. A benzene: methylene chloride $=1: 1$ elution system with the addition of $10 \%$ methanol was used. Detection of spots 
was carried out with the help of a developer, which is phosphomolybdic acid with subsequent heating of the plates for 2-3 min.

\section{Preparative HPLC}

The preparative separations were performed on Kromasil C18 column $(250 \times 20 \mathrm{~mm}, 5-\mu \mathrm{m}$ particle size), and the column temperature was set at $25^{\circ} \mathrm{C}\left( \pm 1{ }^{\circ} \mathrm{C}\right)$. The mobile phase consisted of water - acetonitrile (94:6). The flow rate was $5 \mathrm{~mL} / \mathrm{min}$ in isocratic mode, and the detection wavelength of $\mathrm{UV}$ detector was $195 \mathrm{~nm}$. Samples were dissolved in water (1:5).

\section{Analytical HPLC}

Substances $1 \mathrm{a}$ and $1 \mathrm{~b}$ were separated on Target ODS-3 HD $(250 \times 4.6 \mathrm{~mm}, 5 \mu \mathrm{m}$ particle size $)$ and Zorbax SB-Aq $(150 \times 4.6 \mathrm{~mm}, 5 \mu \mathrm{m}$ particle size). Full selective separation of glycolurils were carried out using Luna $5 \mathrm{u}$ PFP (2) $100 \AA$ ( $150 \times 4.6 \mathrm{~mm}, 5 \mu \mathrm{m}$ particle size). The mobile phase consisted of water and acetonitrile in gradient mode: $0 \mathrm{~min}-5 \%$ of acetonitrile, $1.5 \mathrm{~min}-25 \%$ of acetonitrile, $4 \mathrm{~min}-25 \%$ of acetonitrile. Summary time was $4.5 \mathrm{~min}$; temperature of column was $30^{\circ} \mathrm{C}$; flow rate was $1.5 \mathrm{~mL} / \mathrm{min}$, the detection wavelength of UV detector was $195 \mathrm{~nm}$. Samples were dissolved in water at the ratio 1:1000.

\section{Column chromatography}

Silica gel Silpearl UV 254 (SP) was used as a sorbent to separate the isomers by column chromatography. The eluent was mixture of benzene with methylene chloride in ratio $1: 1$ with the addition of $10 \%$ of methanol. Through the sorbent-filled chromatographic column, the eluent was allowed to swell until the sorbent was completely swollen. $1.5 \mathrm{~g}$ Of a sample of N,N'-DMGU was dissolved in the eluent. A solution of N,N'-DMGU was transferred to a chromatography column using a dispenser, then the eluent was added. Fractions containing isomers were collected with $R_{\mathrm{f}} 0.75$ and 0.25 , spot detection was performed with phosphomolybdic acid. The solvent was distilled off from the combined fractions, and the residue was dried.

\section{NMR spectroscopy}

The samples were analyzed on a Bruker AVANCE 400 III HD (400 MHz) NMR spectrometer. Onedimensional spectra were recorded on the ${ }^{1} \mathrm{H}$ (frequency $400.17 \mathrm{MHz}$ ) and ${ }^{13} \mathrm{C}$ (frequency $100.63 \mathrm{MHz}$ ) nuclei to confirm structures of the samples studied. Dimethyl sulfoxide DMSO- $\mathrm{d}_{6}$ (mass fraction of deuterium $99.9 \%$ ) and $\mathrm{D}_{2} \mathrm{O}$ were used as solvents.

\section{Thermogravimetric analysis}

Spectra were recorded on a STA 449 F1 (Netzsch) instrument combined with a quadrupole mass spectrometer QMS $403 \mathrm{D}$ Aëolos (Netzsch). Measurement conditions were as follows heating rate $-10^{\circ} \mathrm{C} / \mathrm{min}$, working gas flow (Ar) $50 \mathrm{~mL} / \mathrm{min}$, shield gas flow (Ar) $20 \mathrm{~mL} / \mathrm{min}$. The measurements were carried out in an aluminum crucible. The baseline correction was carried out before the measurements.

\section{Results and Discussion}

The synthesis of compounds $1 \mathrm{a}$ and $1 \mathrm{~b}$ is represented by the following scheme:

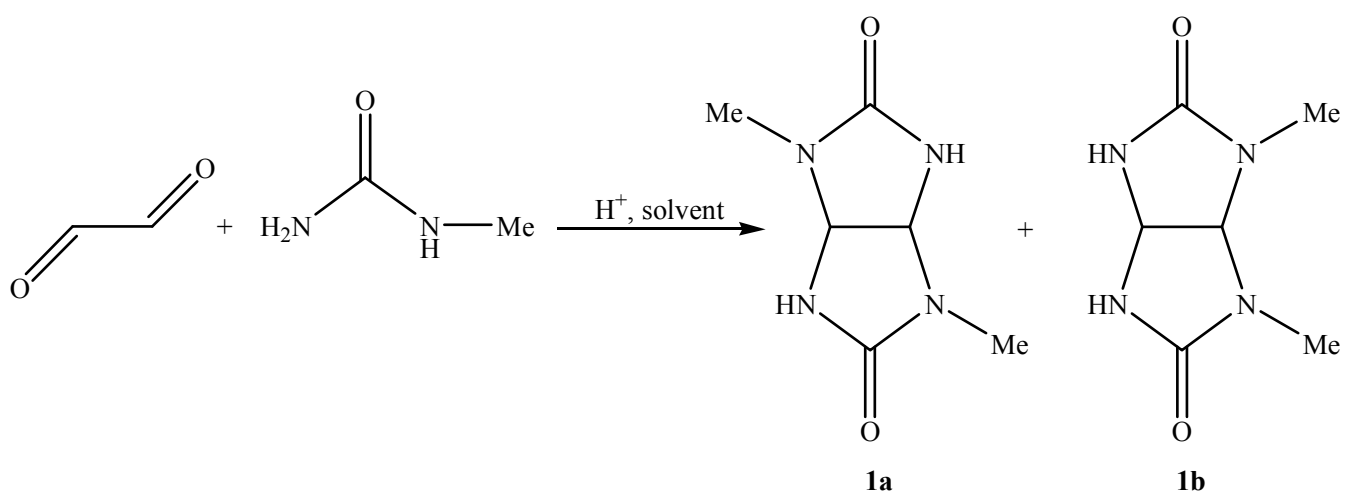

We should separate the mixture of regioisomers $1 \mathrm{a}$ and $1 \mathrm{~b}$, and also characterize these compounds. To solve this problem, we developed a method for separating the trans- and cis- isomers of dimethylglycoluril under HPLC analysis conditions (Fig. 1). 


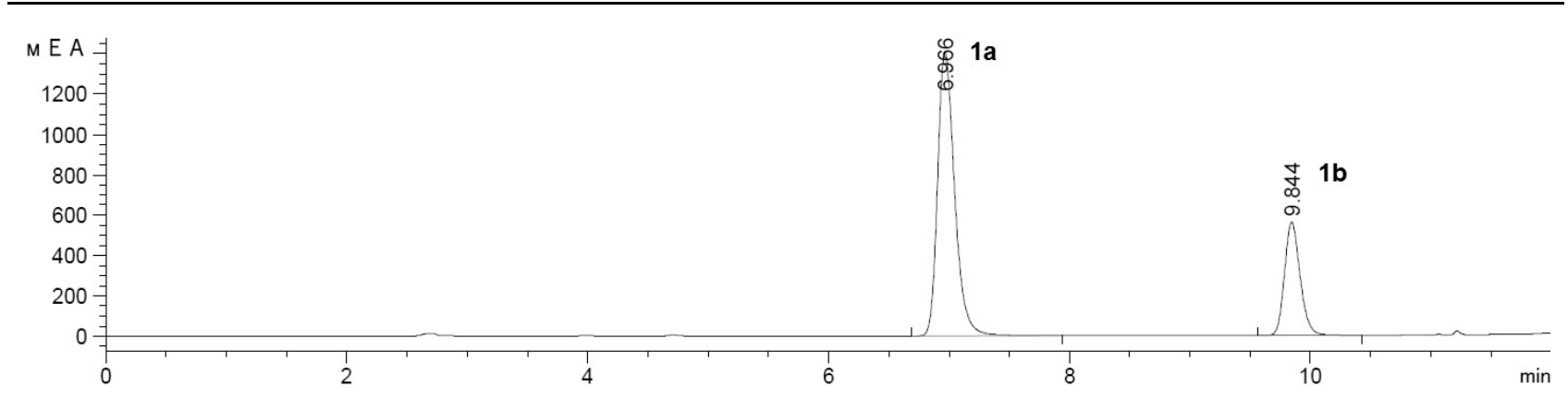

Figure 1. HPLC of $1 \mathrm{a}$ and $1 \mathrm{~b}$

Accordingly, the regioisomers of DMGU 1a and 1b were effectively separated with retention times, namely, $6.998 \mathrm{~min}$ for 1a and $9.704 \mathrm{~min}$ for 1b, as shown in Figure 1, under the investigated HPLC conditions. The obtained results formed the basis for the subsequent development of more convenient preparative HPLC separation of the isomers (the conditions are listed in Experimental). We proposed an alternative method based on preliminary TLC control of the reaction mass, and their subsequent separation by column chromatography to expand the preparative methods for separation of regioisomers of DMGU. Comparison of $1 \mathrm{a}$ and $1 \mathrm{~b}$ obtained by preparative HPLC and column chromatography showed complete identity of their physicochemical properties (TLC, melting point, NMR spectra, TGA analysis).

Recognition of the regioisomers $1 \mathrm{a}$ and $1 \mathrm{~b}$ was carried out by ${ }^{1} \mathrm{H}$ and ${ }^{13} \mathrm{C}$ NMR spectroscopy. Analysis of the ${ }^{1} \mathrm{H}$ NMR spectra showed that the protons of $\mathrm{CH}-\mathrm{CH}$ groups of $1 \mathrm{a}$ were revealed as a singlet signal in the $5.10 \mathrm{ppm}$ range, whereas $\mathrm{CH}-\mathrm{CH}$ groups of $1 \mathrm{~b}$ are split in the form of AMX in the 5.10-5.19 ppm range due to their nonequivalence, which indicates the asymmetry of this structure. Chemical shifts of NH protons in trans- and cis- regioisomers appear as singlets at $7.57 \mathrm{ppm}$ and $7.40 \mathrm{ppm}$, respectively, and the $-\mathrm{CH}_{3}$ groups resonate in the region of $2.61 \mathrm{ppm}$ for the trans- isomer 1a and $2.78 \mathrm{ppm}$ for the cis-isomer $1 \mathrm{~b}$. In the ${ }^{13} \mathrm{C}$ NMR spectra, we showed the presence of the equivalent $\mathrm{CH}-\mathrm{CH}$ groups in the region of $67.39 \mathrm{ppm}$ in the trans- isomer $1 \mathrm{a}, \mathrm{C}=\mathrm{O}$ in the $159.66 \mathrm{ppm}$ region, and $-\mathrm{CH}_{3}$ in the region of $27.42 \mathrm{ppm}$. Whereas $2-\mathrm{CH}-$ $\mathrm{CH}$ group of the cis-isomer is not equivalent and resonate in the $60.63 \mathrm{ppm}$ and $75.63 \mathrm{ppm}$ region, $\mathrm{C}=\mathrm{O}$ in the region of $160.19 \mathrm{ppm},-\mathrm{CH}_{3}$ in the region of $27.43 \mathrm{ppm}$. The unambiguous assignment of signals in ${ }^{1} \mathrm{H}$ and ${ }^{13} \mathrm{C}$ NMR spectra of regioisomers allows them to be reliably recognized in the mixture.

DSC-MS analyzed the individual compounds in the temperature range of $50-450{ }^{\circ} \mathrm{C}$ for the first time to study the thermal behavior of trans- and cis-isomers $1 \mathrm{a}$ and $1 \mathrm{~b}$. The data are presented in Figures 2 and 3.

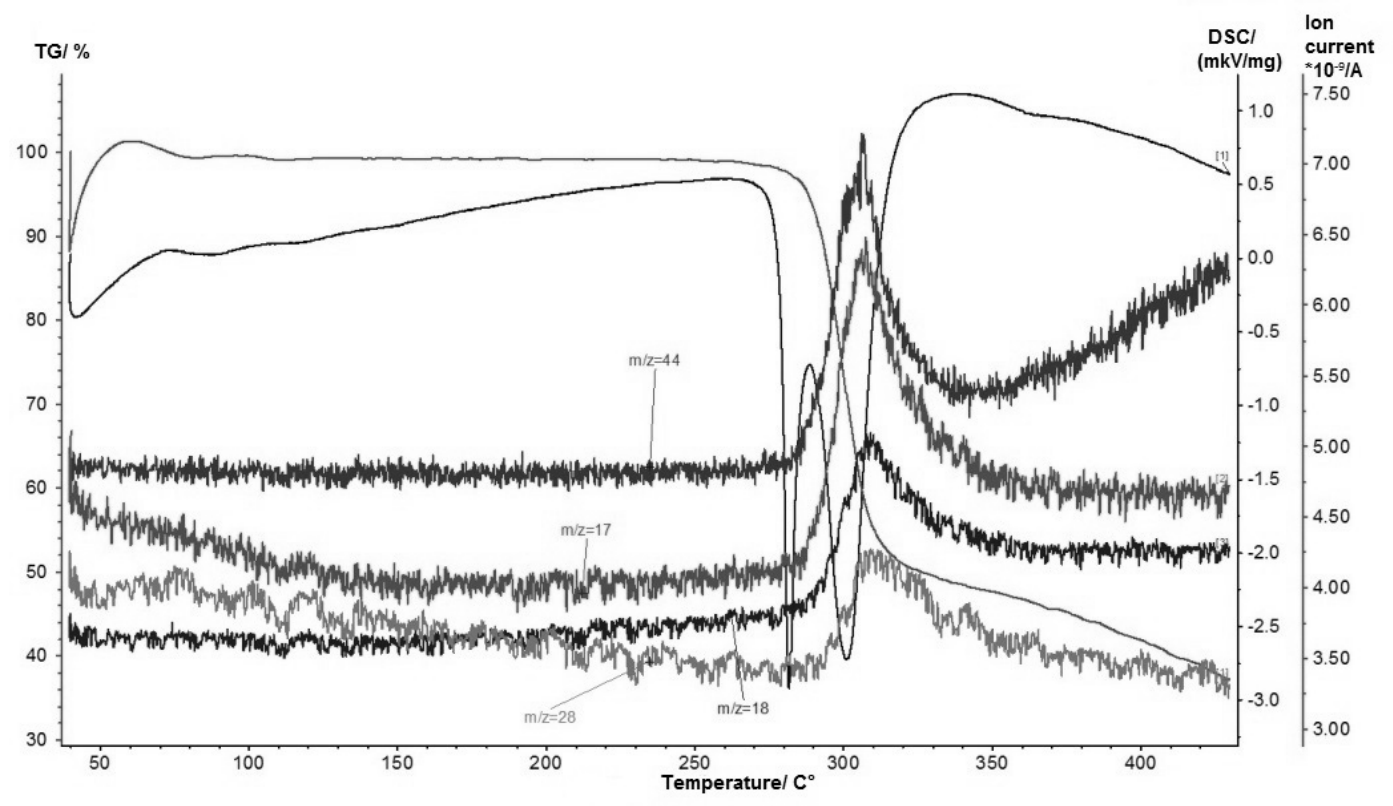

Figure 2. Thermal analysis of Compound 1a 
It can be seen from the DSC curve in Figure 2 that there is a transition at $278^{\circ} \mathrm{C}$, which indicates the melting of compound la, whereas the next phase transition at $300^{\circ} \mathrm{C}$ indicates the decomposition of the substance due to the presence of thermal decomposition products $\mathrm{CO}_{2}, \mathrm{H}_{2} \mathrm{O}, \mathrm{N}_{2}$ in the mass spectra.

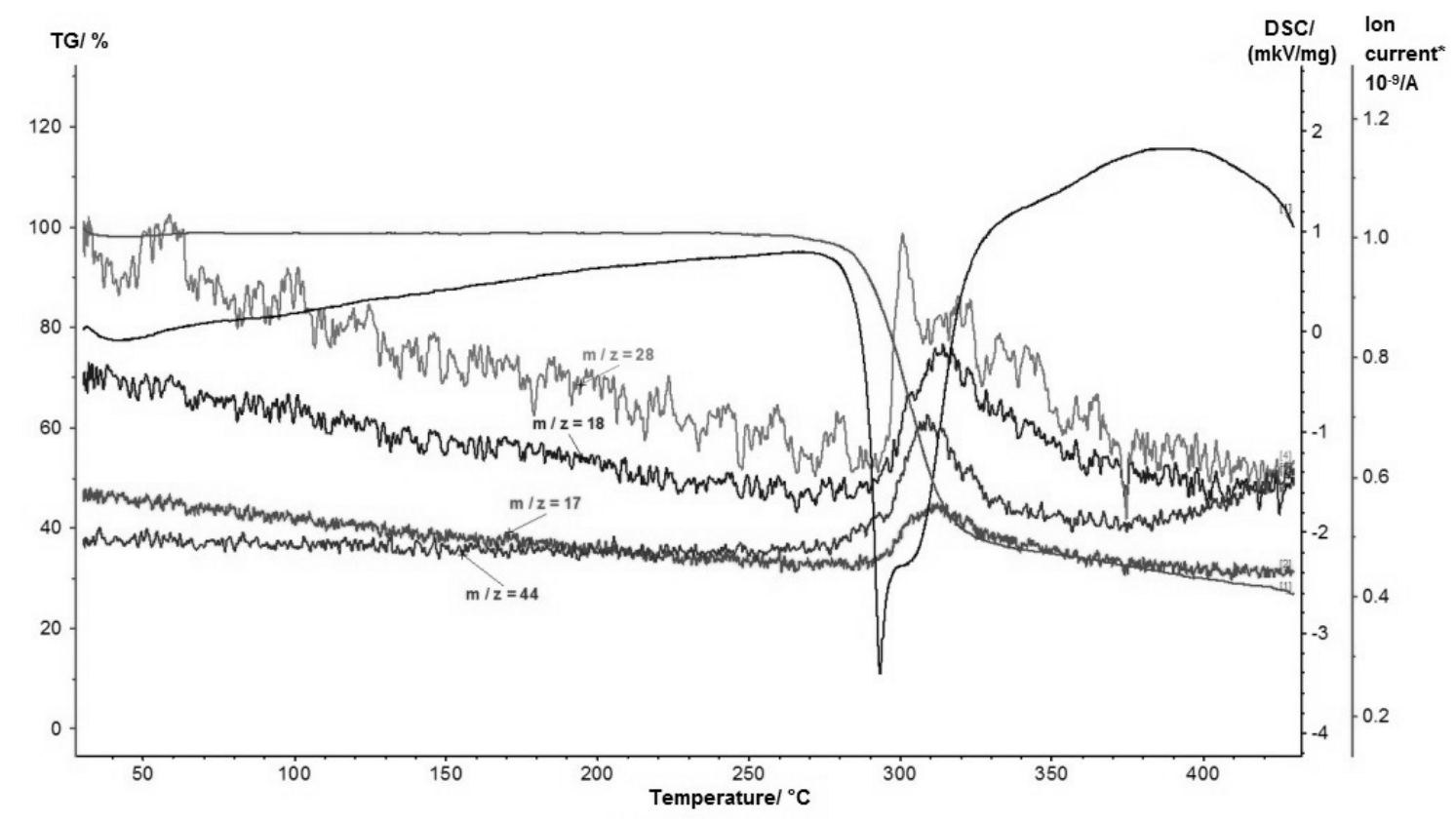

Figure 3. Thermal analysis of Compound $1 \mathrm{~b}$

The data of DSC curve of compound $1 \mathrm{~b}$ (Fig. 3) show that the phase transition at $291{ }^{\circ} \mathrm{C}$ corresponds to the melting process of the substance, and then the transition at $300{ }^{\circ} \mathrm{C}$ indicates the decomposition of the substance, since there are thermal decomposition products $\mathrm{CO}_{2}, \mathrm{H}_{2} \mathrm{O}, \mathrm{N}_{2}$ in the mass spectra.

Since we succeeded in developing reliable methods for the control and identification of isomers 1a and $1 \mathrm{~b}$, in the next stage of our work we studied the reactions of N-methylurea with glyoxal under conditions of strong acid catalysis, which was previously neglected. Thus, in a series of experiments, we showed that the predominant formation of isomer 1a under the conditions found agrees with the literature data [3-8], when this process was carried out in water and alcohols, but not in methanol. But, at the same time, attention is drawn to the fact that the use of perchloric acid (see Table, synthesis 3, 5) or in a separate case of methanol (Table, synthesis 2) significantly increases the regiospecificity of the formation of isomer 1a.

T a ble

Conditions of N,N'-dimethylglycoluril synthesis

\begin{tabular}{|c|c|c|c|c|c|}
\hline No. & Solvent & Catalyst & $1 \mathrm{a}$ & $1 \mathrm{~b}$ & Yield, $\%$ \\
\hline 1 & $\mathrm{CH}_{3} \mathrm{OH}$ & $\mathrm{HCl}$ & 64.75 & 35.25 & 29 \\
\hline 2 & $\mathrm{CH}_{3} \mathrm{OH}$ & $\mathrm{H}_{2} \mathrm{SO}_{4}$ & 91.94 & 8.05 & 30 \\
\hline 3 & $\mathrm{CH}_{3} \mathrm{OH}$ & $\mathrm{HClO}_{4}$ & 89.37 & 10.62 & 33 \\
\hline 4 & $\mathrm{CH}_{3} \mathrm{COOH}$ & $\mathrm{H}_{2} \mathrm{SO}_{4}$ & 65.12 & 34.88 & 42 \\
\hline 5 & $\mathrm{CH}_{3} \mathrm{COOH}$ & $\mathrm{HClO}_{4}$ & 93.15 & 6.85 & 26 \\
\hline
\end{tabular}

Known mechanisms for the formation of glycolurils from urea and glyoxal in the presence of acids imply consideration of sequential and sometimes parallel processes of $\alpha$-ureidoalkylation and cyclization of intermediate mono- and diureidocarbinols [4-9] or acid catalysis of cyclization of ureas with 1,2-dicarbonyl compounds according to Butler [10]. 


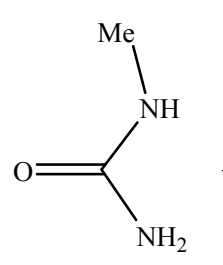

,

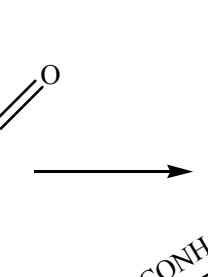

$=$
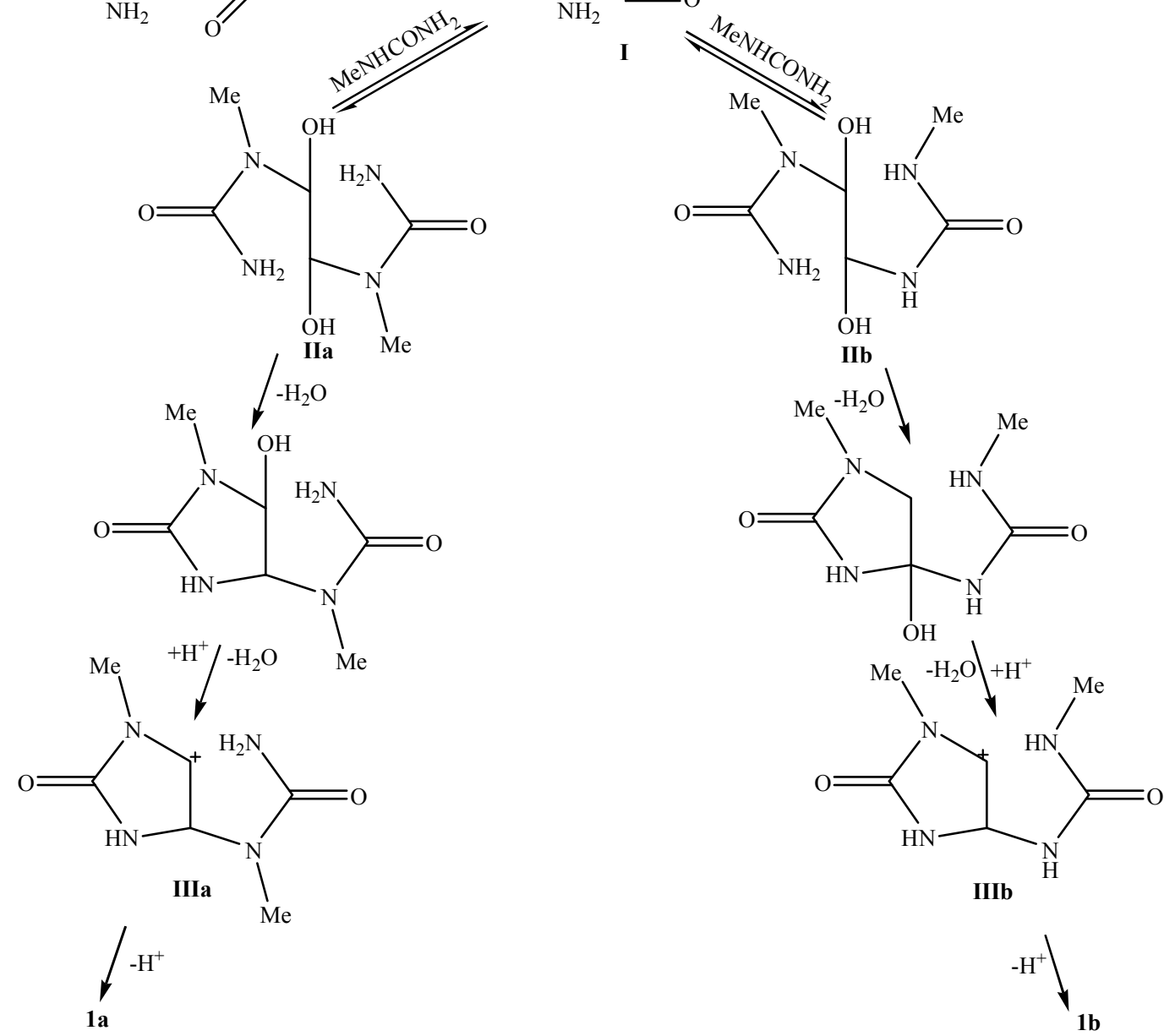

Figure 4. The probable chemical behavior of $1 \mathrm{a}$ and $1 \mathrm{~b}$

According to the above scheme (Fig. 4), the predominant formation of one or the other isomer 1a and $1 \mathrm{~b}$ depends primarily on the propensity to form intermediate bisureidocarbinols IIa and IIb, the formation of which is critically important for the possibility of a competitive nucleophilic attack of $\mathrm{C}=\mathrm{O}$ of glyoxal groups on $-\mathrm{NH}$ and $-\mathrm{NH}_{2}$ in methylurea. In view of the foregoing, under the conditions of synthesis studied, the overwhelming regiospecific formation of isomer $1 \mathrm{a}$ in syntheses 2,3 and 5 is most likely determined by two reasons: the suppression of the nucleophilicity of the secondary $\mathrm{NH}$ group due to its probable protonation under strongly acidic conditions on the one hand and the parallel steric inhibitory effect of $\mathrm{CH}_{3}$-groups on processes of cyclization of intermediate IIIa and IIIb.

\section{Conclusions}

The HPLC conditions of analysis allow efficiently separating the regioisomers of DMGU $1 \mathrm{a}$ and $2 \mathrm{~b}$ with retention times, namely, $6.998 \mathrm{~min}$ for $1 \mathrm{a}$ and $9.704 \mathrm{~min}$ for $1 \mathrm{~b}$. To expand the preparative possibilities for the separation of regioisomers of DMGU, we proposed an alternative method based on preliminary TLC control of the reaction mass, and their subsequent separation by column chromatography (conditions are given in the experimental part). Comparison of the samples of compounds $1 \mathrm{a}$ and $1 \mathrm{~b}$ obtained by preparative HPLC separation and column chromatography showed complete identity of their physicochemical properties (TLC, mp, NMR spectra, TGA analysis).

Thus, in this work it was established that the reaction of glyoxal with $\mathrm{N}$-methylurea under strong acid conditions was completed mainly by the formation of trans-isomer la, in some cases reaching $90 \%$ 
regiospecificity. In addition, the set of physical and chemical studies of regioisomers $1 \mathrm{a}$ and $1 \mathrm{~b}$ made it possible to reliably and unambiguously characterize these isomers.

\title{
References
}

1 Машковский М.Д. Лекарственные средства: пособие для врачей / М.Д. Машковский. - М.: Новая волна, 2005. — $1164 \mathrm{c}$.

2 Прокопов А.А. Изучение экскреции альбикара из организма крыс / А.А. Прокопов, Н.В. Костебелов, А.С. Берланд // Хим.-фарм. журн. - 2002. - № 3. - С. 13, 14.

3 Nematollahi J. Imidazoimidazoles. I. The Reaction of ureas with glyoxal. Tetrahydroimidazo[4,5-d]imidazole-2,5-diones-1,2 / J. Nematollahi, R. Ketchman // J. Org. Chem. - 1963. - Vol. 28. - P. 2378-2380.

4 Grillon E. Isolation and X-ray structure of the intermediate dihydroxyimidazolidine (DHI) in the synthesis of glycoluril from glyoxal and urea / E. Grillon, R. Gallo, M. Pierrot, J. Boiledau, E. Wimmer // Tetrahedron Letters. — 1987. — Vol. 29. — P. 1015, 1016.

5 Gautam S. Synthesis of Unsymmetrically Substituted Hexahydroimidazo [4,5-d]Imidazole-2,5-diones-1,2 / S. Gautam, R. Ketchman, J.J. Nematollahi // Synth. Commun. — 1979. — No. 9. — P. 863.

6 Petersen H. Synthesis of cyclic ureas by ureidoalkylation / H. Petersen // Synthesis. — 1973. — No. 5. — P. $243-292$.

7 Кравченко А.Н. Синтез гликолурилов и их аналогов / А.Н. Кравченко, В.В. Баранов, Г.А. Газиева // Успехи химии. - 2018. - Т. 87, Вып. 1. - С. 107, 108.

8 Kravchenko A.N. Synthesis of new chiral mono-, di-, tri-, and tetraalkylglycolurils / A.N. Kravchenko, A.S. Sigachev, E.Yu. Maksareva, G.A. Gazieva, N.S. Trunova, B.V. Lozhkin et al. // Russian Chemical Bulletin. — 2005. — Vol. 54, No. 3. P. 691-704.

9 Petersen H. Reaction mechanisms, structure and properties of methylol compounds / H. Petersen // Textilveredlung. — 1968. - No. 3. - P. 51.

10 Butler A. Mechanistic studies in the chemistry of urea. Part 4. reaction of urea, 1-methylurea, and 1,3-dimethylurea with benzil in acid solution / A. Butler, I. Hussain, E. Leitch // Journal of the Chemical Society, Perkin Transactions II. — 1980. — No. 2. - P. 103 .

\author{
В.Р. Кущербаева, А.А. Бакибаев, Д.А. Кургачев, \\ А.Ғ. Жақсыбаева, В.С. Мальков, О.А. Котельников
}

\section{N,N-диметилгликолурил кеңістіктік изомерлерінің қышқылды-катализдеуші синтезі мен аналитикалық препараты бөлінуін зерттеу}

\begin{abstract}
Мақала психофармакологиялық белсенділіктің кең спектрін сипаттайтын органикалық қосылыстардың перспективті сыныбы болып табылатын алкилгликолурилдерге арналған. N,N-диметилгликолурил кеңістіктік изомерлердің синтезін катализаторларды (күкірт қышқылы, тұз қышқылы, хлор қышқылы) пайдалану мен әртүрлі ерітінділерде (метанол, сілті қышқылы, құмырсқа қышқылы) өткізді. Реакциялық қоспаның сандық және сапалы құрамын жоғары тиімді сұйықтық хроматографиясы, жұқақабатты-хроматография көмегімен жүзеге асырды. N,N-диметилгликолурилдің жеке кеңістіктік изомерлерін бөлуді препаративті жоғары тиімді сұйықтық хроматография және бағаналы хроматография әдістері мен орындады. Бөліп алынған жеке изомерлердің физика-химиялық қасиеттері ядролық-магнитті спектроскопияның, термогравиметриялық талдаудың көмегімен өлшенді. N,N-диметилгликолурилдің транс- және иис-изомерлерін жоғары тиімді сұйықтық хроматографияның жағдайында аналитикалық анықтау әдісі дайындалды, ұстау уақыты: трансүшін - 6,998 мин, цис- үшін - 9,704 мин. N,N'-диметилгликолурилдың цис- және транс-изомерлері олардың физикалық-химиялық қасиеттерінің толық сәйкестігін анықтады. Қатты сілтілі жағдайларда глиоксальдің N-метилмочевинамен реакциясы транс-изомердің, жекелеген жағдайларда 90 \%-ды региоспецификалықты басым түзілуі мен аяқталатыны белгілі. Цис- және транс-изомерлерінің физикалық-химиялық жиынтығын зерттеу осы изомерлердің физикалық-химиялық қасиеттерін сенімді және бір мағыналы сипаттауға мүмкіндік берді.
\end{abstract}

Кілm сөздер: гликолурил, диметилгликолурил, мочевина, гетероциклдер, циклдену, жоғары тиімді сұйықтық хроматография, бағаналы хроматография, препаративті хроматография. 


\title{
В.Р. Кущербаева, А.А. Бакибаев, Д.А. Кургачев, А.Г. Жаксыбаева, В.С. Мальков, О.А. Котельников
Исследование кислотно-катализируемого синтеза и аналитического препаративного разделения пространственных изомеров N,N-диметилгликолурила

\begin{abstract}
Статья посвящена алкилгликолурилам, являющимся перспективным классом органических соединений, характеризующихся широким спектром психофармакологической активности. Синтез пространственных изомеров N,N-диметилгликолурила проводили в различных растворителях (метанол, уксусная, муравьиная кислоты) с использованием катализаторов (серной, соляной, хлорной кислот). Количественный и качественный состав реакционной смеси проводили с помощью высокоэффективной жидкостной хроматографии, тонкослойной хроматографии. Выделение индивидуальных пространственных изомеров $\mathrm{N}, \mathrm{N}$-диметилгликолурила проводили с помощью препаративной высокоэффективной жидкостной хроматографии и колоночной хроматографии. Физико-химические свойства выделенных индивидуально изомеров были измерены с помощью ядерно-магнитной спектроскопии, термогравиметрического анализа. Разработан метод аналитического определения транс- и изис-изомеров $\mathrm{N}, \mathrm{N}$-диметилгликолурила в условиях высокоэффективной жидкостной хроматографии с временами удерживаний: для транс- - 6,998 мин, для иис- - 9,704 мин. Индивидуально выделены иис- и транс-изомеры N,N'-диметилгликолурида. Сравнение образцов цис- и транс-изомеров, полученных с помощью препаративной высокоэффективной жидкостной хроматографии и колоночной хроматографии, показало полную идентичность их физико-химических свойств. Установлено, что реакция глиоксаля с N-метилмочевиной в сильнокислотных условиях завершается преимущественно с образованием транс-изомера, в отдельных случаях достигая 90 \%-ной региоспецифичности. Совокупность физико-химических исследований ицс- и транс-изомеров позволила надежно и однозначно охарактеризовать физико-химические свойства данных изомеров.
\end{abstract}

Ключевые слова: гликолурил, диметилгликолурил, мочевина, гетероциклы, циклизация, высокоэффективная жидкостная хроматография, колоночная хроматография, препаративная хроматография.

\section{References}

1 Mashkovskii, M.D. (2005). Lekarstvennye sredstva [Medicines]. Moscow: Novaia volna [in Russian].

2 Prokopov, A.A., Kostebelov, N.V., \& Berland, A.S. (2002). Izuchenie ekskretsii albikara iz orhanisma krys [Study of excretion of albicar from the body of rats]. Khimiko-farmatsevticheskii zhurnal - Pharmaceutical Chemistry Journal, 3, 13-16 [in Russian].

3 Nematollahi, J., \& Ketchman, R. (1963). Imidazoimidazoles I. The Reaction of ureas with glyoxal. Tetrahydroimidazo[4,5d]imidazole-2,5-diones-1,2. J. Org. Chem, 28, 2378-2380.

4 Grillon, E., Gallo, R., Pierrot, M., Boiledau, J., \& Wimmer, E. (1987). Isolation and X-ray structure of the intermediate dihydroxyimidazolidine (DHI) in the synthesis of glycoluril from glyoxal and urea. Tetrahedron Letters, 29, 1015-1016.

5 Gautam, S., Ketchman, R., \& Nematollahi, J. (1979). Synthesis of Unsymmetrically Substituted Hexahydroimidazo[4,5d]Imidazole-2,5-diones-1,2. J. Synth. Commun, 9, 863.

6 Petersen, H. (1973). Synthesis of cyclic ureas by ureidoalkylation. Synthesis, 5, 243-292.

7 Kravchenko, A.N., Baranov, V.V., \& Gazieva, G.A. (2018). Sintez hlikolurilov i ikh analohov [Synthesis of glycolurils and their derivatives]. Moscow: Uspekhi khimii [in Russian].

8 Kravchenko, A.N., Sigachev, A.S., Maksareva, E.Yu., Gazieva, G.A., Trunova, N.S., \& Lozhkin, B.V., et al. (2005). Synthesis of new chiral mono-, di-, tri- and tetraalkylglycolurils. Russian Chemical Bulletin, 54, 691-704.

9 Petersen, H. (1968). Reaction mechanisms, structure, and properties of methylol compounds. Textilveredlung, 3, 51.

10 Butler, A., Hussain, I., \& Leitch, E. (1980). Mechanistic studies in the chemistry of urea. Part 4. Reaction of Urea, 1-methylurea, and 1,3-dimethylurea with benzil in acid solution. Journal of the Chemical Society, Perkin Transactions II, $2,103$. 